\title{
Autoimmune Encephalopathies and Epilepsies in Children and Teenagers
}

\author{
Lily C. Wong-Kisiel, Andrew McKeon, Elaine C. Wirrell
}

\begin{abstract}
Recognition of autoimmune encephalopathies and epilepsies in children and teenagers with acute or subacute onset of central nervous system dysfunction, through detection of the pertinent antibody on serum or cerebral spinal fluid, or through a response to immunotherapy may lead to an early diagnosis, and thus expedited implementation of immunotherapy and improved neurological outcome. The epidemiology of pediatric autoimmune encephalopathy and epilepsy is not well established, but advances in disease-specific biomarker discovery have lead to identification of disorders with either a cytotoxic $\mathrm{T}$ cell mediated pathogenesis or (more recently) possible autoantibody mediated disorders. This review summarizes the clinical presentations and recommended evaluations and treatment of pediatric epileptic encephalopathy suspected to be of autoimmune etiology.
\end{abstract}

RÉSUMÉ: Encéphalopathies auto-immunes et épilepsies chez les enfants et les adolescents. L'identification des encéphalopathies et des épilepsies auto-immunes par la détection des anticorps appropriés dans le sérum ou le liquide céphalo-rachidien ou à cause d'une réponse à l'immunothérapie, chez les enfants et les adolescents qui présentent une dysfonction subaiguë du système nerveux central, peut mener à un diagnostic précoce ainsi qu'à l'administration rapide du traitement par immunothérapie et donc améliorer le pronostic neurologique. L'épidémiologie de l'encéphalopathie et de l'épilepsie auto-immunes n'est pas bien connue. Cependant la découverte de biomarqueurs spécifiques de la maladie ont mené à l'identification de maladies ayant soit une pathogenèse cytotoxique médiée par les cellules $\mathrm{T}$ ou (plus récemment) de maladies probablement auto-immunes. Cette revue fait un sommaire du tableau clinique, des évaluations et des traitements recommandés de l'encéphalopathie épileptique pour laquelle on soupçonne une étiologie auto-immune.

Can J Neurol Sci. 2012; 39: 134-144

Autoimmune etiologies are being increasingly recognized as causes of encephalopathies and intractable epilepsy in both children and adults. This area has received a lot of attention in recent years, with the rapid pace of disease-specific immunoglobulin $\mathrm{G}$ ( $\mathrm{IgG}$ ) biomarker discovery, and since these disorders are treatable (unlike most other etiologies leading to these presentations), early diagnosis and initiation of effective therapy are essential to limit the devastating neurological sequelae which may occur.

\section{Etiology}

Etiologically, autoimmune neurological disorders fall into three broad groups: paraneoplastic, parainfectious, or idiopathic. Central nervous system (CNS) disorders that have been established as having a parainfectious etiology include acute disseminated encephalomyelitis, autoimmune cerebellitis, and pediatric autoimmune neuropsychiatric disorders associated with streptococcal infections. Opsoclonus-myoclonus ataxia syndrome occurs on a paraneoplastic or parainfectious basis in childhood. Systemic lupus erythematosus has been associated with neuropsychiatric manifestations. For the most part, this discussion will be limited to autoimmune encephalitides and epilepsies secondary to idiopathic or paraneoplastic etiology

\section{Pathophysiology}

Both cytotoxic T cells and effector IgG antibodies are known to be important in the pathophysiology of neural injury in autoimmune neurological disorders. The neural-specific IgG biomarkers detected in the course of clinical evaluation are generally regarded in one of two ways. The first category includes antibodies to intracellular antigens (nuclear or cytoplasmic). While these serve as disease biomarkers of a cytotoxic $\mathrm{T}$ cell-mediated pathogenesis, the most cogent evidence points to these antibodies not being pathogenic. The most detailed investigations have occurred in adult patients, but is likely relevant to the pediatric population in some

From the Division of Child and Adolescent Neurology, Department of Neurology (LCWK, ECW), Departments of Laboratory Medicine and Pathology, and Neurology (AM), Mayo Clinic College of Medicine, Rochester, Minnesota.

Received June 2, 2011. Final Revisions Submitted October 7, 2011. Correspondence to: Elaine Wirrell, Division of Child and Adolescent Neurology, Department of Neurology, Mayo Clinic College of Medicine; 200 First Street, SW; Rochester, Minnesota, 55905, USA. 
circumstances. The target antigen of PCA-1 ('anti-Yo', relevant in adult female patients with breast and ovarian carcinoma), cdr2, is a cytoplasmic antigen and therefore unlikely to be accessible to circulating antibody. A neural peptide-specific $\mathrm{T}$ cell-mediated attack on neurons has been established as the basis of irreversible neurological impairment in PCA-1-IgG-positive patients ${ }^{1}$. Antigen-specific cytotoxic $\mathrm{T}$ cells are likely activated by dendritic cells presenting cdr2 peptides to the circulating $\mathrm{T}$ cell. The expanded populations of MHC class I-restricted, CD8+ onconeural peptide-specific cytotoxic $\mathrm{T}$ lymphocytes emigrate from tumor-draining lymph nodes to the systemic circulation and then to the CNS causing neuronal degeneration. These patients usually respond poorly to immunotherapy ${ }^{2}$.

The second category includes autoantibodies directed against cell-membrane synaptic proteins or receptors, and these antibodies may be pathogenic through cross-linked IgG mediated antigenic-modulation and complement activation. Pathogenicity has been established in animal models (active immunization and passive transfer) for two disorders: myasthenia gravis - the prototypic antibody-mediated neurological disorder ${ }^{3,4}$ and autoimmune dysautonomia ${ }^{5,6}$. For CNS disorders, definitive in vivo proof for pathogenicity of any neural antibody is thus far lacking. However, antibody-mediated cytotoxicity likely plays a role in these disorders because many patients respond well to antibody depleting therapy. Patients with $N$-methyl-D-aspartate (NMDA) receptor antibody or voltage-gated potassium channel (VGKC) complex associated antibody frequently improve with plasma exchange, intravenous immune globulin or corticosteroids. Furthermore, in vitro models have suggested a pathogenic role. Hughes et al demonstrated that $\mathrm{IgG}$ from NMDA receptor antibody seropositive patients caused a selective and reversible decrease in NMDA receptor density and synaptic localization, through antigenic degradation and endocytosis, with corresponding reduction in NMDA receptor-mediated currents on patch-clamp recordings and a reduction in NMDA receptors in the hippocampi of rats infused with patients' antibodies ${ }^{7}$.

\section{Epidemiology}

The proportion of children with epilepsy who harbor autoantibody markers has not been well-studied. While one publication reported that nearly $50 \%$ of children with epilepsy were antinuclear antibody (ANA) positive ${ }^{8}$, other studies reported much lower rates of less than $2 \%^{9,10}$. Similarly, despite the potential association of celiac disease and epilepsy, an Italian study found no difference between the prevalence of gliadin and tissue transglutaminase antibodies in children with epilepsy and controls ${ }^{11}$. The prevalence of other types of autoantibodies has been assessed predominantly in adults with epilepsy, and no population-based studies have been performed. Studies done on epilepsy clinic populations may have a selection bias for more refractory cases. In one study of 106 women with long-standing, drug-resistant epilepsy, Majoie et al found elevated titers of VGKC complex antibodies in 6\%, and antibodies targeting the $65-\mathrm{Kd}$ isoform of glutamic acid decarboxylase (GAD65) in none ${ }^{12}$. Another study detected GAD65 antibody in $2.8 \%$ of adult patients with epilepsy in an outpatient neurology clinic ${ }^{13}$. Nearly $90 \%$ of the GAD65 positive patients had temporal lobe epilepsy and the presence of GAD65 antibodies did not correlate with seizure frequency, epilepsy surgery or duration of epilepsy. All patients with GAD65 antibody had multiple autoantibodies detected, and $71 \%$ had other autoimmune diseases such as thyroiditis, type I diabetes, celiac disease, and juvenile rheumatoid arthritis, as well as other immune-mediated disorders (asthma and demyelinating disease). No study has yet reported the prevalence of NMDA receptor antibodies in a population with epilepsy. However, in a recent retrospective review of seven young adults admitted to the intensive care unit for encephalitis of unknown origin, six $(86 \%)$ were found to have NMDA receptor antibodies ${ }^{14}$.

\section{Clinical presentations}

The clinical presentations associated with various disorders are described in detail throughout this review. Limbic encephalitis is a classical autoimmune CNS disorder with manifestations of encephalopathy and seizures. Symptoms suggesting limbic encephalitis include severe memory loss and cognitive dysfunction, irritability and personality change and seizures. While diagnostic criteria for classical limbic encephalitis have been published ${ }^{15}$, presentations are often not classical, and non-limbic presentations also frequently occur. Faciobrachial dystonic seizures are highly resistant to antiepileptic drug treatment and characterized by unilateral or alternating facial grimaces simultaneous with ipsilateral arm dystonia, lasting a few seconds associated with brief loss of awareness, with median frequency of 50 times per day ${ }^{16,17}$. Multifocal and subacute presentations of developmental regression, movement disorders, insomnia, focal and generalized seizures, and status epilepticus illustrate the diverse neurologic manifestations among children with VGKC complex-reactive autoantibodies $^{18,19}$. An autoimmune etiology should be considered in subacute neurologic presentations of unknown cause.

\section{Differential diagnosis}

The differential diagnosis of acute or subacute encephalopathy with or without seizures in children is broad and requires a high index of suspicion (Table 1). Infectious etiologies include herpes simplex encephalitis and human herpesvirus 6 infections. Herpes simplex encephalitis typically presents with a much more rapid progression, greater alteration in consciousness and higher rates of focal neurological deficits. The cerebrospinal fluid (CSF) usually shows a more marked inflammatory response and polymerase chain reaction testing is usually positive. Human herpesvirus 6 has been reported to cause symptoms similar to limbic encephalitis in immunecompromised patients ${ }^{20}$. Vasculitis may present in childhood with symptoms of headache, aseptic meningitis, encephalopathy, stroke, seizures and neuropathy ${ }^{21}$. An elevated erythrocyte sedimentation rate is often present (but may be normal), and with the exception of primary angiitis of the central nervous system, systemic involvement of the kidney, lung, skin, joints, gastrointestinal (GI) tract and eye are usually seen. In primary angiitis of the central nervous system, vascular inflammation is multifocal, with a predilection to involve small arteries in the leptomeninges ${ }^{22}$. 
Table 1: Differential diagnosis of acute and subacute encephalopathy in children

\begin{tabular}{|c|c|}
\hline Acute & $\begin{array}{l}\text { Hypoglycemia } \\
\text { Hyper/Hyponatremia } \\
\text { Uremia } \\
\text { Hepatic encephalopathy } \\
\text { Inborn errors such as amino or organic acidopathy, urea cycle disorder, } \\
\text { mitochondrial disorder, fatty acid oxidation disorder, pyruvate metabolism } \\
\text { disorder, carnitine deficiency, porphyria }\end{array}$ \\
\hline Vascular: & $\begin{array}{l}\text { Hypertensive encephalopathy } \\
\text { Posterior reversible encephalopathy syndrome } \\
\text { Subarachnoid bleed } \\
\text { Ischemic stroke } \\
\text { Anoxic encephalopathy }\end{array}$ \\
\hline Toxins: & $\begin{array}{l}\text { Post radiation } \\
\text { Substance abuse } \\
\text { Prescription drugs } \\
\text { Toxins (heavy metals, organophosphates, alcohol) }\end{array}$ \\
\hline Head trau & uma \\
\hline Subacut & $\begin{array}{l}\text { e } \\
\text { Bacterial meningitis } \\
\text { Viral meningoencephalitis (Arbovirus, Herpes simplex, HHV6, measles, HIV) } \\
\text { Mycoplasma encephalitis } \\
\text { Cat scratch disease } \\
\text { Rickettsial infection } \\
\text { Abscess }\end{array}$ \\
\hline Postinfec & $\begin{array}{l}\text { tious: } \\
\text { Acute disseminated encephalomyelitis } \\
\text { Reye's syndrome } \\
\text { Acute necrotizing encephalopathy }\end{array}$ \\
\hline Inflamma & $\begin{array}{l}\text { tory: } \\
\text { Vasculitis } \\
\text { Other inflammatory disease: multiple sclerosis, Behcet's }\end{array}$ \\
\hline Endocrine & $\begin{array}{l}\text { e: } \\
\text { Thyroid disorders } \\
\text { Parathyroid disorders } \\
\text { Adrenal insufficiency }\end{array}$ \\
\hline Structura & $\begin{array}{l}\text { I: } \\
\text { Brain tumour } \\
\text { Hydrocephalus }\end{array}$ \\
\hline Migraine: & $\begin{array}{l}\text { Acute confusional migraine } \\
\text { Transient global amnesia }\end{array}$ \\
\hline Epilepsy: & Absence or partial status epilepticus \\
\hline Psychiatr & $\begin{array}{l}\text { ic: } \\
\text { Conversion disorder } \\
\text { Psychosis }\end{array}$ \\
\hline
\end{tabular}

\section{Autoimmune encephalopathies associated with non-neurological autoimmunity}

Clinical suspicion for an autoimmune encephalopathy may arise in the context of another established autoimmune disorder or serological finding, either organ specific (for example, thyroid autoimmunity) or non-organ specific (systemic lupus erythematosus). Essentially, the diagnosis of each of these depends on a triad of acute or subacute onset of CNS dysfunction, serological detection of the pertinent antibody and a response to immunotherapy.

\section{SREAT (formerly known as Hashimoto's encephalopathy)}

Steroid responsive encephalopathy with autoimmune thyroiditis (SREAT) ${ }^{23}$ has also been known historically as Hashimoto's encephalopathy. The clinical presentation includes confusion, seizures, psychosis, dementia, or stroke-like symptoms ${ }^{24}$, with acute or subacute onset, and a relapsingremitting or monophasic course. Diagnostic investigations reveal high levels of thyroid autoantibodies (thyroid peroxidase and thyroglobulin antibodies), electroencephalogram (EEG) abnormalities (often non-specific), and increased CSF protein concentration. Many patients are euthyroid or have a history of autoimmune thyroid disease, but are euthyroid at the time of neurological presentation. Magnetic resonance image (MRI) abnormalities show nonenhancing abnormalities in $25 \%$ of patients with SREAT during subacute exacerbations ${ }^{23}$. A vasculopathic basis for the disorder has been hypothesized since lymphocytic perivascular cuffs and vasculitis of venules and arterioles have been noted in some patients ${ }^{25}$ and diffusionweighted MRI abnormalities have been noted in others ${ }^{26}$. Limited epidemiology data on SREAT include a prevalence of 2.1/100,000 based on estimates from a hospital setting, with median age of disease onset between $44-56$ years ${ }^{27}$.

Steroid responsive encephalopathy with autoimmune thyroiditis in the pediatric population is predominately described in case reports. In a survey directed at identification of pediatric SREAT in the UK and Ireland, Gayatri et al identified ten patients, who showed female predominance, mean age at presentation of 12 years, the majority of whom presented with seizures and encephalopathy ${ }^{28}$. Cognitive impairment manifested by decline in school performance persisted beyond the acute episode. Thyroid antibody values did not correlate with disease severity or response to treatment ${ }^{29}$. Immunoglobulins and corticosteroids treatments were guided by neuropsychological assessment because long-term cognitive deficits and relapsing course were identified in about a third of the patients ${ }^{30}$.

\section{Celiac disease and neurological autoimmunity}

Celiac disease is an immune-mediated small bowel disease triggered by gluten proteins in genetically susceptible individuals. The estimated prevalence is between 0.3 and $1.1 \%$ among children and adults ${ }^{31,32}$. Neurological complications include cerebellar ataxia and peripheral neuropathy. The association with epilepsy and central nervous system disorders is much debated. The often cited study on epilepsy in patients with celiac disease reports the prevalence of epilepsy to be $5 \%$, but epilepsy cases were identified through patient questionnaire and physician interview without supporting clinical records ${ }^{33}$. Other authors found no difference in the prevalence of epilepsy between patients with celiac disease and the general population ${ }^{34,35}$. Similar findings were found in case control studies $^{36,37}$. A systematic review showed a risk difference close to zero, suggesting a chance association between two common disorders, despite a relative risk of epilepsy of 2.1 in children with celiac disease and a relative risk of celiac disease of 1.7 in children with epilepsy ${ }^{38}$.

Celiac disease and epilepsy with occipital calcifications is a distinct entity first described in Italy and subsequently described in other populations. Bilateral cortico-subcortical calcifications are seen located in the parieto-occipital area, without brain atrophy ${ }^{39}$. The mean age of seizure onset is around six years ${ }^{39,40}$. Visual seizures (simple hallucinations) are common, followed by complex seizures or secondary generalization. Seizures typically respond to antiepileptic drugs, but some patients show improved 
seizure control with a gluten-free diet. The pathogenesis of this disorder is unknown.

\section{Systemic lupus erythematosus (SLE)}

Neuropsychiatric manifestations of SLE in children are a common cause of morbidity and mortality. Central nervous system symptoms generally occur early in the course with $40 \%$ being present at initial presentation, and $70 \%$ occurring within the first year after diagnosis ${ }^{41}$. While headache is the most common symptom, affecting nearly two thirds of cases, other neuropsychiatric symptoms include psychosis, cognitive dysfunction, cerebrovascular disease, mood disorders, and chorea. Seizures are seen in approximately $20 \%$ of cases, and are commonly associated with cerebrovascular disease and/or cognitive dysfunction ${ }^{41}$. No antibody marker specific for neuropsychiatric disease has been firmly established for clinical use to date. An autoimmune neuropsychiatric disorder occurring in the setting of lupus should be considered in the presence of systemic symptoms of SLE including arthritis, rash, nephritis, unexplained fever, pericarditis or oral ulcers, or where double stranded DNA (dsDNA) antibody and ANA are detected. Antinuclear antibody detected in isolation is quite non-specific, but may serve as a clue to autoimmunity nonetheless.

\section{Antibody markers of CNS autoimmunity and common associated clinical features}

We have confined our discussion to those antibody markers that have been described in relation to pediatric and adolescent autoimmune epilepsies as follows (Table 2).

\section{Antibodies targeting cell surface antigens \\ Voltage-gated potassium channel complex antibody}

Voltage-gated potassium channel complex autoimmunity is associated with limbic encephalitis, other forms of encephalitis with epilepsy, cognitive impairment as well as dysautonomia, dyssomnia, brainstem, cranial nerve and peripheral nerve dysfunction in adults ${ }^{42-44}$. Voltage-gated potassium channel complex (Kv1 type) is critical for regulating neuronal excitability. In addition to VGKCs, these complexes contain cell adhesion molecules, membrane-associated guanylate kinases, cytoskeletal scaffold, disintegrin and metalloproteinase 22 (ADAM22), and a soluble binding partner of ADAM22, leucinerich, glioma inactivated 1 (Lgi1) protein, which was first recognized as an epilepsy-linked protein ${ }^{45,46}$. Some evidence suggests that autoantibodies identified in clinical radioimmunoassays target neuronal proteins that coimmunoprecipitate with detergent-solubilized VGKCs. The principal antigens identified to date include Lgil in patients with

Table 2: Autoimmune epilepsies and associated antibodies in children and teenagers

\begin{tabular}{|c|c|c|}
\hline Antibodies & Clinical presentation & Supportive diagnostic tests \\
\hline \multicolumn{3}{|c|}{ Antibodies targeting cell surface antigens (likely pathogenic) } \\
\hline Voltage-gated potassium channel & $\begin{array}{l}\text { Hyponatremia, autonomic dysfunction, } \\
\text { hypothermia, sleep problems, limbic } \\
\text { encephalitis, status epilepticus, } \\
\text { faciobrachial dystonic seizures. }\end{array}$ & $\begin{array}{l}\text { Serum VGKC antibody, CSF normal or mildly elevated } \\
\text { white cell count, protein; } \pm \text { CSF exclusive oligoclonal } \\
\text { bands; asymmetric mesial temporal T2/FLAIR signal } \\
\text { abnormalities. }\end{array}$ \\
\hline NMDA receptor & $\begin{array}{l}\text { Flue-like prodrome, cognitive } \\
\text { dysfunction (confusional, behavioral } \\
\text { change, amnesia), seizures, } \\
\text { dyskinesias, autonomic instability } \\
\text { (central hypoventilation). }\end{array}$ & $\begin{array}{l}\text { CSF NMDA receptor antibody, CSF lymphocytosis, } \\
\text { CSF exclusive oligoclonal bands early, MRI brain } \\
\text { often normal. }\end{array}$ \\
\hline NMO-lgG & $\begin{array}{l}\text { Neuromyelitis optica, encephalopathy, } \\
\text { seizures, optic neuritis and transverse } \\
\text { myelitis. }\end{array}$ & Serum NMO-IgG antibody, MRI brain and spine. \\
\hline $\begin{array}{l}\text { AMPA receptor \& } \\
\text { GABA }_{B} \text { receptor }\end{array}$ & Limbic encephalitis & $\begin{array}{l}\text { Serum AMPA GluR1/GluR2 antibody or } \mathrm{GABA}_{B} \\
\text { receptor antibody. }\end{array}$ \\
\hline \multicolumn{3}{|c|}{ Antibodies against intracellular antigenic targets (markers of a cytotoxic T cell mediated pathogenesis) } \\
\hline ANNA-1 (anti-Hu) & $\begin{array}{l}\text { Limbic encephalitis, brainstem } \\
\text { encephalitis, peripheral neuropathies. }\end{array}$ & $\begin{array}{l}\text { Serum ANNA-1 antibody, elevated VMA/HVA or } \\
\text { imaging suggestive of neuroblastoma. }\end{array}$ \\
\hline Ma2 & $\begin{array}{l}\text { Limbic, diencephalic and brainstem } \\
\text { encephalitides in boys. }\end{array}$ & $\begin{array}{l}\text { Serum Ma2 antibody, testicular ultrasound for germ } \\
\text { cell tumors }\end{array}$ \\
\hline GAD65 & $\begin{array}{l}\text { Temporal lobe epilepsy and } \\
\text { anterograde amnesia, cerebellar ataxia, } \\
\text { brainstem disorders, stiff-man } \\
\text { syndrome. }\end{array}$ & Serum GAD65 antibody \\
\hline
\end{tabular}


limbic encephalitis and faciobrachial dystonic seizures, and contactin-associated protein 2 (Caspr2) in patients with acquired neuromuscular hyperexcitability, steroid-responsive peripheral neuropathies, dysautonomias and encephalopathies ${ }^{47,48}$

This entity is possibly less common in children. Kroll-Seger et al reported a 13-year-old girl with characteristic clinical symptoms and elevated VGKC antibody ${ }^{49}$. From stored serum of children with unexplained encephalopathy and presenting with status epilepticus, Suliemen et al found four of ten cases to test positive for VGKC antibody compared to $1 / 69$ controls $(\mathrm{p}<0.001)^{18}$. Other clinical clues to VGKC-associated CNS disorders include hyponatremia, autonomic dysfunction, hypothermia and sleep problems. The CSF is usually normal or shows only a mild elevation in white cell count or protein. Cerebrospinal fluid exclusive oligoclonal bands may be present. Magnetic resonance imaging studies frequently show abnormal signal increase on T2 or FLAIR images in the mesial temporal regions (Figure). This signal change is frequently asymmetric and contrast enhancement is usually not seen. Underlying malignancy should be excluded - a recent retrospective study found that $10 \%$ of children and teens with limbic encephalitis had cancer ${ }^{50}$. Hodgkins lymphoma, testicular tumors, ovarian teratomas and neuroblastoma are the most common associated tumor types. Dhamija et al recently reported one case of neuroblastoma among 12 children seropositive for VGKC complex autoantibody ${ }^{19}$. Response to treatment is often

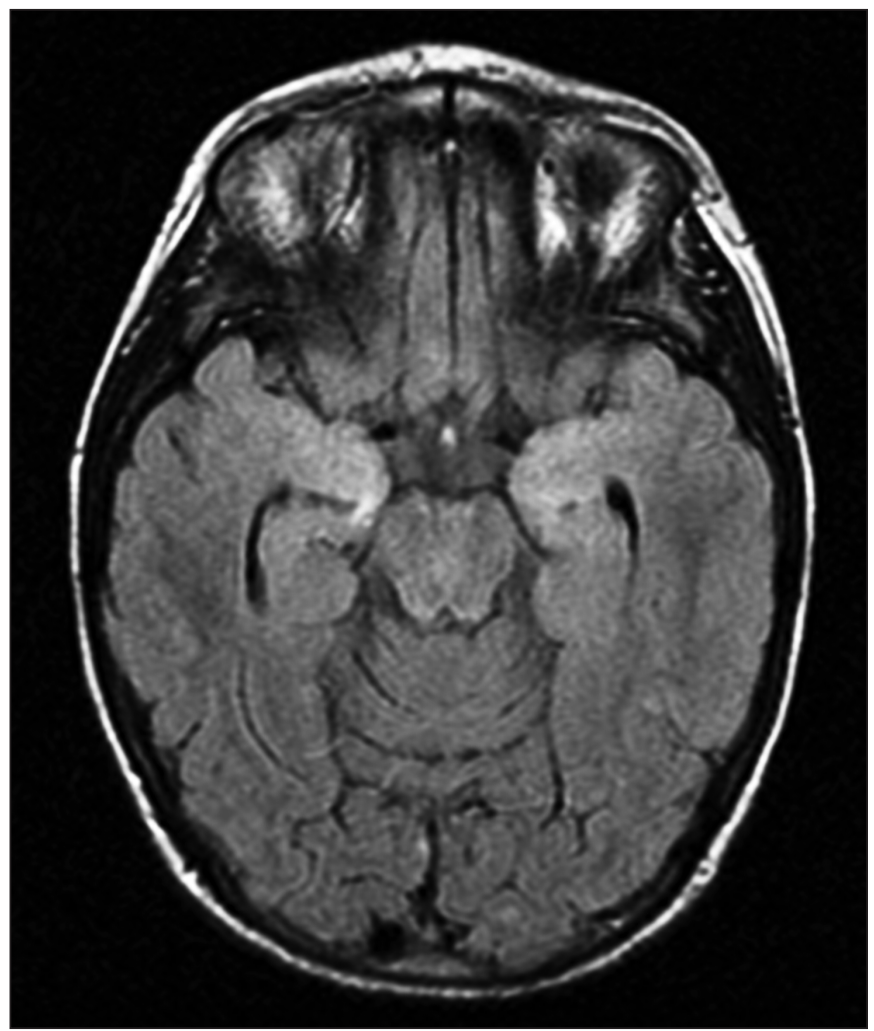

Figure: T2 hyperintensity in bilateral mesiotemporal lobes of an eight year-old girl with VGKC limbic encephalitis. favorable with prompt initiation of one or more of corticosteroids, intravenous immune globulin (IVIg), plasma exchange or immunosuppression.

\section{NMDA receptor antibodies}

Antibodies targeting the NR1 subunit of the NMDA subtype of ionotropic glutamate receptors were first reported among young women with ovarian teratoma ${ }^{51}$. About $59 \%$ of adult patients had an identified tumor when assessed ${ }^{52}$. The incidence of neoplasm detection is highest in young and middle-aged women, and is lower in children ${ }^{53-55}$ and the elderly. Neoplasms are infrequently found in male patients ${ }^{54}$.

The clinical course for NMDA receptor antibody encephalitis is subacute, often preceded by a flu-like prodrome. Early features during the first few days include psychiatric symptoms, and, in the largest series to date, $70 \%$ of patients were initially diagnosed with a primary psychiatric disorder ${ }^{52}$. Cognitive dysfunction such as confusion, behavioral changes, amnesia, and seizures ensued. Seizures are typically extratemporal ${ }^{56}$. Other features include dyskinesias, autonomic dysfunction, and decreased level of consciousness often requiring ventilatory support ${ }^{55,57}$. In children, the most common presentations were behavioral and personality changes, seizures, and sleep dysfunctions ${ }^{54,55}$. Late manifestations include dyskinesias and autonomic instability. This disorder should also be considered in patients with drug-resistant epilepsy and acute-onset complex partial status epilepticus.

In non-selected case series of all comers evaluated for autoimmune studies to a central European laboratory, $11 \%$ of the referred sera were positive for NMDA receptor antibodies ${ }^{55}$. Coexisting autoantibodies were detected in about $12 \%$ of NMDA receptor antibody positive cases, and included VGKC complex antibodies and thyroid peroxidase antibodies. Cerebrospinal fluid analysis showed lymphocytosis present during the first month of symptom onset which became absent afterwards. In contrast, CSF-exclusive oligoclonal bands are often absent early at presentation but may appear late in the disease course in about $40 \%$ of patients ${ }^{55}$. Magnetic resonance imaging is often normal. Electroencephalograms show epileptiform discharges during the early phase, with subsequent generalized slowing. Clinical improvements may be dramatic when early immunotherapy and tumor removal are instituted $^{52,55,57}$. Prolonged intensive supportive care and immunotherapy (often months) is often required to ensure an optimal clinical recovery. Patients treated with immunotherapy late in the clinical course generally do poorly ${ }^{51}$.

\section{Neuromyelitis optica (NMO)-IgG}

Neuromyelitis optica is classically characterized by relapsing and severe optic neuritis and transverse myelitis in adults. In 2004, an autoantibody marker with high specificity for the disorder was reported ${ }^{58}$, and subsequently a broader clinical spectrum in children and adolescents emerged which included encephalopathy and seizures ${ }^{59,60}$. In one series, which evaluated the clinical presentations of 58 pediatric NMO-IgG seropositive patients, consecutively evaluated serologically at Mayo Clinic, the authors reported $16 \%$ of patients presented with brain symptomatology, and $45 \%$ developed brain symptomatology at 
some point in the clinical course (as well as optic neuritis and transverse myelitis) $)^{59}$. Clinical presentations included encephalopathy, seizures and $11 \%$ had mesial temporal lobe abnormalities on MRI.

\section{AMPA GluR1/GluR2 antibody}

This is a rarely detected antibody and, to date, no pediatric cases have been reported. Antibodies to the glutamate receptor 1 (GluR1) and GluR2 subunits of the alpha-amino-3-hydroxy-5methyl-4-isoxazolepropionic acid (AMPA) receptor were recently described among patients with limbic encephalitis ${ }^{61}$. From a single institution's experience with limbic encephalitis, positive AMPA GluR1/GluR2 autoantibodies represented 10/43 patients previously thought to have antibodies targeting an unknown antigen. The median age of symptom onset was 60 years (range 38-87 years), with female predominance, and often with a paraneoplastic association; seven of ten patients had underlying neoplasm of the thymus, breast, or lung ${ }^{61}$. Relapses occurred in about half of the patients, irrespective of use of oncologic therapy. Coexisting autoimmune disorders and autoantibodies were common. A pathogenic role for AMPA GluR1/GluR2 autoantibodies was hypothesized since reduced clustering and localization of the AMPA receptors was observed at the synapses in hippocampal cultures.

\section{$G A B A_{B}$ receptor antibody}

Lancaster et al recently reported patients (all adults, usually with small cell carcinoma) with limbic encephalitis with prominent seizures that present early in the course, who were found to have antibodies to the metabotropic gammaaminobutyric acid (GABA) receptor ${ }^{62}$. These patients also had a high frequency of other autoantibodies, particularly GAD65 antibody. It remains to be seen in larger studies if this antibody marker will be pertinent to evaluation of children and teens.

\section{Antibody markers of cytotoxic $\mathbf{T}$ cell mediated disorders}

Paraneoplastic limbic encephalitis is predominantly $\mathrm{T}$ cell mediated and autoantibodies are directed against intracellular antigenic targets ${ }^{63}$. Unfortunately, these disorders respond poorly to immunotherapy. Antineuronal nuclear antibody type 1 (ANNA-1, also known as 'anti-Hu') is the most commonly identified autoantibody in this category in children, associated with neuroblastoma and multifocal neurological presentations including limbic encephalitis, brainstem encephalitis and peripheral neuropathies ${ }^{63-65}$. Autoimmunity targeting Ma2 proteins is associated with limbic, diencephalic and brainstem encephalitides in boys with germ cell testicular tumors ${ }^{66,67}$. The oncological associations are more diverse in patients who have coexisting Ma1 antibody, and the neurological prognosis is often poorer.

\section{GAD65 antibody}

Glutamic acid decarboxylase 65 is the rate-limiting enzyme for the synthesis of GABA. It is an intracellular target, selectively expressed in GABA-ergic neurons and in pancreatic B-cells. Glutamic acid decarboxylase 65 antibody is generally a marker of thyrogastric autoimmunity, including type 1 diabetes mellitus, pernicious anemia and autoimmune thyroid disease.
Associations with neurological autoimmunity (including autoimmune epilepsy) are generally seen with very high antibody values (>20.0 nmol/L, while most diabetics have values around $1.00 \mathrm{nmo} / \mathrm{L})^{68,69}$. Neurologic disorders associated with GAD65 antibody include stiff-man syndrome ${ }^{70}$, brainstem disorders ${ }^{69}$, cerebellar ataxia, and limbic encephalitis ${ }^{71}$. Low GAD65 antibody values are common in the general population (about $2 \%)^{72}$ and among relatives of patients with type 1 diabetes $^{73}$. The frequency of GAD65 antibody positivity among patients with epilepsy is low ( $<1$ to $6 \%$ of patients $)^{69,74-76}$. The majority of the patients with GAD65 antibody associated encephalopathies present with temporal lobe epilepsy and associated anterograde amnesia ${ }^{69,77-79}$. Most patients have multiple coexisting autoantibodies and nearly a third of patients have other autoimmune disease $\mathrm{e}^{69,77}$. The majority of patients have no identifiable tumor despite an extensive $\operatorname{search}^{69,79}$.

\section{Rasmussen's Encephalitis}

Rasmussen's encephalitis was first described in 1958 and remains an important cause of intractable epilepsy, particularly in children ${ }^{80}$. Patients progress with focal seizures at escalating frequency, hemispheric atrophy ipsilateral to the focal seizures, and progressive contralateral motor dysfunction. Histological examination of the brain shows perivascular lymphocytic cuffing, microglial nodules, and loss of neurons with gliosis. Classically, the disease lateralizes to one hemisphere, although rare bilateral cases are described. In 1994, Rogers et al reported the presence of glutamate receptor 3 antibody in several patients with Rasmussen's encephalitis, one of whom responded to plasma exchange ${ }^{81}$. Further work however did not confirm these findings ${ }^{82}$, and currently, the pathogenesis of Rasmussen encephalitis is thought to be similar to that of some paraneoplastic neurological disorders (CD8+-cytotoxic T cellmediated $)^{83}$. The results of treatment with immunotherapies (steroids, IVIg, plasmapheresis and immunosuppressive agents) have been disappointing, and do not reduce the incidence of hemispherectomy in affected patients ${ }^{84}$.

\section{Evaluation of autoimmune encephalopathy and encephalitis: How and Who to Test?}

Autoimmune disorders are increasingly being recognized as a potential etiology for seizure disorders ${ }^{85}$. Potential associations with occult neoplasm make accurate diagnosis imperative to allow timely initiation of immunotherapy and early cancer diagnosis. Infectious prodrome, fevers without apparent etiology, neuropsychiatric symptoms prior to an acute or subacute onset of neurologic presentations, including partial or generalized seizures refractory to conventional antiepileptic drugs may be clues suggestive of an underlying autoimmune etiology (Table 3). Improved seizure control associated with steroid, which is often prescribed for childhood respiratory illness, may reveal an unsuspected response to immunotherapy. Distinct clinical spectrum such as autonomic dysfunction and oral dyskinesia may suggest NMDA receptor antibody encephalitis and direct the clinician to investigate NMDA receptor antibody in the CSF. 


\section{Table 3: Clinical clues suggestive of an underlying autoimmune etiology in a child or teen presenting with seizures}

- $\quad$ Altered mental status or delirium

- Recent memory impairment or cognitive dysfunction

- Acute or subacute presentation

- Rapidly progressive or fluctuating course

- Multifocal neurological symptoms and signs

- Autonomic dysfunction

- Sleep disorders

- Movement disorder including oral dyskinesias

- FLAIR or T2 signal changes on MRI

- Slowing of background on EEG

- Inflammatory CSF (Elevated white cell count elevated protein, CSF exclusive oligoclonal bands, elevated $\lg G$ index or synthesis rate).

- Evidence of co-existing autoimmunity or seropositivity for organ-specific or non organ-specific autoantibodies

- Family history of autoimmunity or seropositivity for organ-specific or non organ-specific autoantibodies

Evaluation of a patient with possible autoimmune encephalopathy should include the following ${ }^{86}$

\section{A. Exclusion of other underlying etiologies}

In children, the evaluation should include screening for underlying toxic or metabolic conditions (Table 1). Children should be evaluated for underlying infectious etiologies, including intracranial infections such as encephalitis, meningitis, or abscess, or postinfectious encephalopathies.

\section{B. Documentation of neurological findings and cognitive and psychiatric dysfunction}

A thorough neurological examination should be documented; findings are frequently multifocal. A neuropsychological evaluation should be considered to document objectively cognitive function, and evaluate other mitigating factors such as depression or anxiety. Magnetic resonance imaging assists in ruling out other underlying etiologies, and may show T2 hyperintensity in some, but not all types of autoimmune encephalopathy. The mesial temporal lobe is commonly affected in autoimmune encephalopathies; however the MRI may be normal. In other instances there may be extratemporal MRI abnormalities. Functional neuroimaging with either positron emission tomography (PET) or single-photon emission computed tomography (SPECT) can reveal focal areas of abnormal metabolism which correspond to clinical symptoms. Electroencephalogram findings are non-specific but often show focal or generalized background slowing, and epileptiform abnormalities. Electroencephalogram could also help exclude non-convulsive status epilepticus (which could be a manifestation of an autoimmune epilepsy or a seizure disorder of other etiology).

\section{Testing for further clues to an autoimmune diagnosis}

While most laboratories offer basic autoimmune testing, such as ANA, dsDNA antibodies, thyroglobulin antibodies, and tissue transglutaminase antibodies, more specialized testing for specific antibodies is offered in a limited number of laboratories. Detection of non-neural autoantibodies provides support for, but is not diagnostic of, an autoimmune etiology for the encephalopathy. Comprehensive testing for neural-specific autoantibodies is more informative than testing for individual antibodies since neurological disorders are often multifocal and diverse, and don't always fit the 'classical' syndromes described in the literature ${ }^{87}$. Furthermore, specific antibody profiles guide cancer diagnosis. For instance, VGKC complex antibodies, ANNA-1, Ma2 and NMDA receptor antibodies may all present with features of limbic encephalitis, but the cancer types and positive predictive values for cancer detection differ. Abnormal CSF findings including an elevated white cell count, elevated protein, CSF exclusive oligoclonal bands and elevated IgG index or synthesis rate, provide support, but are not diagnostic of an autoimmune etiology.

\section{Evaluation for an underlying cancer}

'Whole body' (orbits to thighs) MRI or computed tomography (CT) is typically requested at our institution with the addition of urine homovanillic acid and vanillylmandelic acid to screen for neuroblastoma. Cancers can be investigated according to age and sex-specific risk factors. In order of frequency, leukemia, lymphoma, and neuroblastoma are the most common systemic malignancies in children less than 15 years, with Hodgkin disease and germ-cell tumors among teenagers between 15- and 19-years ${ }^{88}$. Fluorodeoxyglucose (FDG) avidity for lymphoma, neuroblastoma and other cancer types has been utilized in FDG-PET/CT to provide additional functional information overlaying anatomical imaging in a single radiographic study compared to conventional imaging such as ultrasound, CT, or MRI ${ }^{89,90}$. Cancer evaluations may also be guided by the antibody finding: testicular exam and ultrasound in a boy seropositive for Ma2; pelvic ultrasound in a girl seropositive for NMDA receptor antibody to exclude ovarian teratoma. Lack of occult neoplasm despite above investigations may support a non-paraneoplastic autoimmune process, but repeated investigations for occult tumor in the presence of onconeural antibody may be warranted.

\section{Therapeutic Options}

Treatment of autoimmune neurological disorders requires prompt immunotherapy and oncological therapy where appropriate, in addition to standard antiepileptic drug therapy. There are no evidence-based guidelines for treatment of children and teens with autoimmune causes for encephalopathy and seizures. Nonetheless, a rational approach to immunotherapy, consisting of a trial of treatment, accompanied by pre and post treatment objective neurological assessments can help establish the presence or absence of therapeutic efficacy. 
Table 4: First line therapeutic options for autoimmune encephalopathy and intractable epilepsy in children and teenagers.

\begin{tabular}{|c|c|c|}
\hline $\begin{array}{l}\text { Therapeutic } \\
\text { options }\end{array}$ & Dose & Major side effects \\
\hline Methylprednisolone & $\begin{array}{l}20-30 \mathrm{mg} / \mathrm{kg} / \mathrm{day} \times 5 \\
\text { days } \\
\text { Usually followed by } \\
\text { weekly dosing, } \\
\text { ultimately aiming to } \\
\text { gradually widen the } \\
\text { dosing interval over } \\
\text { months }\end{array}$ & $\begin{array}{l}\text { Acutely: infection, } \\
\text { hyperglycemia, hypertension, } \\
\text { osteoporosis, avascular } \\
\text { necrosis, edema, acne mood } \\
\text { alterations. } \\
\text { If used chronically: obesity, } \\
\text { growth impairment, cushingoid } \\
\text { appearance, adrenal } \\
\text { suppression, cataracts, } \\
\text { glaucoma }\end{array}$ \\
\hline IVIg & $\begin{array}{l}1-2 \mathrm{~g} / \mathrm{kg} / \mathrm{day} \times 1-2 \text { days } \\
\text { or } 0.4 \mathrm{~g} / \mathrm{kg} / \text { day for } 3-5 \\
\text { days } \\
\text { Usually followed by } \\
\text { weekly dosing, } \\
\text { ultimately aiming to } \\
\text { gradually widen the } \\
\text { dosing interval over } \\
\text { months }\end{array}$ & $\begin{array}{l}\text { Headache, aseptic meningitis, } \\
\text { chest discomfort, tachycardia, } \\
\text { Stevens-Johnson syndrome, } \\
\text { acute renal failure, acute } \\
\text { respiratory failure, } \\
\text { hypersensitivity reaction; } \\
\text { anaphylaxis in IgA-deficient } \\
\text { patients. }\end{array}$ \\
\hline Plasma exchange & $\begin{array}{l}5-7 \text { exchanges on } \\
\text { alternate days for } 10 \text { - } \\
14 \text { days, for acute } \\
\text { severe } \\
\text { symptoms }\end{array}$ & $\begin{array}{l}\text { Paresthesia, muscle cramps, } \\
\text { urticaria, anaphylaxis, line } \\
\text { infection, hypotension, } \\
\text { dyspnea. }\end{array}$ \\
\hline
\end{tabular}

In our own clinical practice, we generally begin with either a trial of intravenous corticosteroids or IVIg, with plasma exchange reserved for those with incomplete response (Table 4). High-dose corticosteroid pulses may consist of $20-30 \mathrm{mg} / \mathrm{kg} / \mathrm{day}$ methylprednisolone for five days ${ }^{91}$. Repeat doses are then usually given weekly initially for a period of six weeks. If a clear objective benefit is observed then this dosing interval can be gradually tapered (every other week for 6-12 weeks, followed by every three weeks for a period of three months and then monthly for a period of three months). Methylprednisolone-equivalents are prednisone doses multiplied by 0.8 , and dexamethasone doses by 5 . Use of corticosteroid is accompanied by gastric prophylaxis and by Pneumocystis carinii pneumonia prophylaxis with trimethoprim/sulfamethoxazole at $5 \mathrm{mg} / \mathrm{kg} / 24 \mathrm{~h}$ administered twice a day on two to three consecutive days per week. Oral steroid taper should be done slowly and cautiously in those who have been treated with steroids for longer than a few weeks, and is best done with the help of an endocrinologist to avoid addisonian crisis. The American College of Rheumatology Task Force on glucocorticoid-induced osteoporosis recommends adult daily calcium intake between $1000 \mathrm{mg}$ and $1500 \mathrm{mg}$ and vitamin D intake at $800 \mathrm{IU} /$ day based on randomized control trials ${ }^{92}$, without specific recommendation made for children. Children ages one year and older could receive the 2011 Institute of Medicine recommended dietary allowance of calcium between 700 and $1300 \mathrm{mg}$ and vitamin D at $600 \mathrm{IU} /$ day $^{93}$.

An initial dose of IVIg $1-2 \mathrm{~g} / \mathrm{kg}$, either as one or two $1 \mathrm{~g} / \mathrm{kg}$ doses given on successive days, or as $0.4 \mathrm{~g} / \mathrm{kg}$ daily for three to five days can be considered as an alternate option. Higher doses of IVIg $(1 \mathrm{~g} / \mathrm{kg})$ may be less well tolerated (headache or aseptic meningitis). Repeat doses are then usually given weekly initially for a period of six weeks. If a clear objective benefit is observed then this dosing interval can be gradually tapered (every other week for 6-12 weeks, followed by every three weeks for a period of three months and then monthly for a period of three months). Plasma exchange with five to seven exchanges on alternate days over 10-14 days is reserved for patients with incomplete responses to the first line therapies or for critically ill patients ${ }^{94}$.

Immunosuppressant medication such as mycophenolate, azathioprine or anti-CD20 antibody rituximab can be added if there is an objective response to steroids or IVIg, to facilitate remission maintenance when tapering steroids or IVIg. For NMDA receptor antibody associated encephalitis, the rituximab at $375 \mathrm{mg} / \mathrm{m}^{2}$ per week for four to six infusions can be considered $^{2,95}$. Dalmau and colleagues have also proposed their own treatment regimen specifically for NMDA receptor antibody seropositive patients, which includes IVIg and steroids in the acute phase as first line therapy, and remission maintenance with mycophenolate or azathioprine ${ }^{51}$. For more severe cases rituximab with or without cyclophosphamide therapy has been recommended. Dysautonomia and central hypoventilation requiring critical care and ventilatory support mandates aggressive and early treatment to prevent mortality. Outcomes from treatment of classical paraneoplastic neurological disorders ( $\mathrm{T}$ cell mediated) with immunotherapy are often disappointing, but improvements may occur with one or more of oncological therapy (particularly for Ma2 patients ${ }^{96}$ ), or cyclophosphamide ${ }^{97}$.

Patients with a highly suggestive clinical history for an autoimmune CNS disorder may be considered for treatment, even in the absence of detection of antibody, once other potential etiologies have been excluded from consideration. In these cases, we usually plan a three month course of corticosteroids or IVIg, as discussed above, and reassess treatment after that time. Given the cost, potential adverse effects and limited availability of intravenous immunoglobulin, patients in whom clinical improvement is not observed are not continued on this therapy. Assessment of response is based on clinical improvements in seizure control, movement disorders, cognition and behavior, as well as measured improvement on neuropsychological testing, T2 or FLAIR signal change on MRI, improvements on EEG (using either routine EEG or video EEG monitoring), reduction of ictal and interictal discharge and improvement in background slowing and CSF and blood studies (reduction in CSF white blood cell count and reduction in antibody titers).

\section{Prognosis}

The prognosis of autoimmune neurological disorders varies, and is dependent on a number of factors, including the pathogenesis (cytotoxic $\mathrm{T}$ cell mediated disorders versus antibody mediated) and timeliness of immunotherapy initiation (early or late). Flanagan et al recently demonstrated that adult patients with autoimmune cognitive disorders in whom treatment was delayed had significantly worse outcomes than those treated early on in the disease course ${ }^{98}$. Faciobrachial dystonic seizures preceded the classic presentation of amnesia, confusion, and temporal lobe seizures in $77 \%$ of adult patients with VGKC-complex limbic encephalitis, and may offer a window of treatment opportunity, as evidenced by three of four 
patients who received immunotherapy early without development of cognitive impairment ${ }^{17}$. Favorable clinical outcomes as demonstrated by reduction in modified Rankin scores were associated with early immunotherapies or tumor removal in patients with NMDA receptor antibody encephalitis ${ }^{55}$.

\section{ConClusion}

Autoimmunity is increasingly recognized as a cause of encephalopathy and seizure disorders in children and teens. Early recognition through clinical and serological diagnosis is important since this may lead to an early diagnosis of cancer, expedited implementation of immunotherapy and improved neurological long-term outcome.

\section{REFERENCES}

1. Albert ML, Darnell JC, Bender A, Francisco LM, Bhardwaj N, Darnell RB. Tumor-specific killer cells in paraneoplastic cerebellar degeneration. Nat Med. 1998;4(11):1321-4.

2. Ishiura $\mathbf{H}$, Matsuda $\mathbf{S}$, Higashihara $\mathbf{M}$, et al. Response of antiNMDA receptor encephalitis without tumor to immunotherapy including rituximab. Neurology. 2008;71(23):1921-3.

3. Lindstrom JM, Lennon VA, Seybold ME, Whittingham S. Experimental autoimmune myasthenia gravis and myasthenia gravis: biochemical and immunochemical aspects. Ann NY Acad Sci. 1976;274:254-74.

4. Lennon VA, Lindstrom JM, Seybold ME. Experimental autoimmune myasthenia gravis: cellular and humoral immune responses. Ann N Y Acad Sci. 1976;274:283-99.

5. Lennon VA, Ermilov LG, Szurszewski JH, Vernino S. Immunization with neuronal nicotinic acetylcholine receptor induces neurological autoimmune disease. J Clin Invest. 2003; 111(6):907-13.

6. Vernino S, Ermilov LG, Sha L, Szurszewski JH, Low PA, Lennon VA. Passive transfer of autoimmune autonomic neuropathy to mice. J Neurosci. 2004;24(32):7037-42.

7. Hughes EG, Peng X, Gleichman AJ, et al. Cellular and synaptic mechanisms of anti-NMDA receptor encephalitis. J Neurosci. 2010;30(17):5866-75

8. Constantin T, Kalovics T, Ponyi A, et al. Prevalence of antiphospholipid and antinuclear antibodies in children with epilepsy. Med Sci Monit. 2009;15(4):CR164-9.

9. Markic J, Mestrovic M, Valic I, Sapunar A, Bosnjak N. Frequency of anticardiolipin, antinuclear and anti-beta2 glycoprotein I antibodies in children with epilepsy. Coll Antropol. 2007;31(3): 739-42.

10. Asadi-Pooya AA, Asadi-Pooya K. Antinuclear antibodies in children with epilepsy treated by carbamazepine. Epilepsy Res. 2008;80(2-3):229-30.

11. Giordano L, Valotti M, Bosetti A, Accorsi P, Caimi L, Imberti L. Celiac disease-related antibodies in Italian children with epilepsy. Pediatr Neurol. 2009;41(1):34-6.

12. Majoie HJ, de Baets M, Renier W, Lang B, Vincent A. Antibodies to voltage-gated potassium and calcium channels in epilepsy. Epilepsy Res. 2006;71(2-3):135-41.

13. Liimatainen S, Peltola M, Sabater L, et al. Clinical significance of glutamic acid decarboxylase antibodies in patients with epilepsy. Epilepsia. 2010;51(5):760-7.

14. Pruss H, Dalmau J, Harms L, et al. Retrospective analysis of NMDA receptor antibodies in encephalitis of unknown origin. Neurology. 2010;75(19):1735-9.

15. Bien CG, Elger CE. Limbic encephalitis: a cause of temporal lobe epilepsy with onset in adult life. Epilepsy Behav. 2007;10(4): 529-38.

16. Irani SR, Buckley C, Vincent A, et al. Immunotherapy-responsive seizure-like episodes with potassium channel antibodies. Neurology. 2008;71(20):1647-8.
17. Irani SR, Michell AW, Lang B, et al. Faciobrachial dystonic seizures precede Lgil antibody limbic encephalitis. Ann Neurol. 2011;69(5):892-900.

18. Suleiman J, Brenner T, Gill D, et al. VGKC antibodies in pediatric encephalitis presenting with status epilepticus. Neurology. 2011; 76(14):1252-5

19. Dhamija R, Renaud DL, Pittock SJ, et al. Neuronal voltage-gated potassium channel complex autoimmunity in children. Pediatr Neurol. 2011;44(4):275-81.

20. Wainwright MS, Martin PL, Morse RP, et al. Human herpesvirus 6 limbic encephalitis after stem cell transplantation. Ann Neurol. 2001;50(5):612-9.

21. Duzova A, Bakkaloglu A. Central nervous system involvement in pediatric rheumatic diseases: current concepts in treatment. Curr Pharm Des. 2008;14(13):1295-301.

22. Lie JT. Primary (granulomatous) angiitis of the central nervous system: a clinicopathologic analysis of 15 new cases and a review of the literature. Hum Pathol. 1992;23(2):164-71.

23. Castillo P, Woodruff B, Caselli R, et al. Steroid-responsive encephalopathy associated with autoimmune thyroiditis. Arch Neurol. 2006;63(2):197-202.

24. Chong JY, Rowland LP, Utiger RD. Hashimoto encephalopathy: syndrome or myth? Arch Neurol. 2003;60(2):164-71.

25. Nolte KW, Unbehaun A, Sieker H, Kloss TM, Paulus W. Hashimoto encephalopathy: a brainstem vasculitis? Neurology. 2000;54(3): 769-70

26. Grommes C, Griffin C, Downes KA, Lerner AJ. Steroid-responsive encephalopathy associated with autoimmune thyroiditis presenting with diffusion MR imaging changes. AJNR Am J Neuroradiol. 2008;29(8):1550-1.

27. Ferracci F, Bertiato G, Moretto G. Hashimoto's encephalopathy: epidemiologic data and pathogenetic considerations. J Neurol Sci. 2004;217(2):165-8.

28. Gayatri NA, Whitehouse WP. Pilot survey of Hashimoto's encephalopathy in children. Dev Med Child Neurol. 2005;47(8): 556-8.

29. Watemberg N, Greenstein D, Levine A. Encephalopathy associated with Hashimoto thyroiditis: Pediatric perspective. J Child Neurol. 2006;21(1):1-5.

30. Vasconcellos E, Pina-Garza JE, Fakhoury T, Fenichel GM. Pediatric manifestations of Hashimoto's encephalopathy. Pediatr Neurol. 1999;20(5):394-8.

31. Maki M, Mustalahti K, Kokkonen J, et al. Prevalence of celiac disease among children in Finland. N Engl J Med. 2003;348(25): 2517-24.

32. Cook HB, Burt MJ, Collett JA, Whitehead MR, Frampton CM, Chapman BA. Adult coeliac disease: prevalence and clinical significance. J Gastroenterol Hepatol. 2000;15(9):1032-6.

33. Chapman RW, Laidlow JM, Colin-Jones D, Eade OE, Smith CL. Increased prevalence of epilepsy in coeliac disease. Br Med J. 1978;2(6132):250-1.

34. Pengiran Tengah DS, Holmes GK, Wills AJ. The prevalence of epilepsy in patients with celiac disease. Epilepsia. 2004;45(10): 1291-3.

35. Hanly JG, Stassen W, Whelton M, Callaghan N. Epilepsy and coeliac disease. J Neurol Neurosurg Psychiatry. 1982;45(8):729-30.

36. Zelnik N, Pacht A, Obeid R, Lerner A. Range of neurologic disorders in patients with celiac disease. Pediatrics. 2004;113(6): 1672-6.

37. Ruggieri M, Incorpora G, Polizzi A, Parano E, Spina M, Pavone P. Low prevalence of neurologic and psychiatric manifestations in children with gluten sensitivity. J Pediatr. 2008;152(2):244-9.

38. Lionetti E, Francavilla R, Pavone P, et al. The neurology of coeliac disease in childhood: what is the evidence? a systematic review and meta-analysis. Dev Med Child Neurol. 2010;52(8):700-7.

39. Arroyo HA, De Rosa S, Ruggieri V, de Davila MT, Fejerman N. Epilepsy, occipital calcifications, and oligosymptomatic celiac disease in childhood. J Child Neurol. 2002;17(11):800-6.

40. Gobbi G. Coeliac disease, epilepsy and cerebral calcifications. Brain Dev. 2005;27(3):189-200.

41. Benseler SM, Silverman ED. Neuropsychiatric involvement in pediatric systemic lupus erythematosus. Lupus. 2007;16(8): $564-71$. 
42. Tan KM, Lennon VA, Klein CJ, Boeve BF, Pittock SJ. Clinical spectrum of voltage-gated potassium channel autoimmunity. Neurology. 2008;70(20): 1883-90.

43. Vincent A, Buckley C, Schott JM, et al. Potassium channel antibody-associated encephalopathy: a potentially immunotherapy-responsive form of limbic encephalitis. Brain. 2004;127 (Pt 3):701-12.

44. Geschwind MD, Tan KM, Lennon VA, et al. Voltage-gated potassium channel autoimmunity mimicking Creutzfeldt-Jakob disease. Arch Neurol. 2008;65(10):1341-6.

45. Schulte U, Thumfart JO, Klocker N, et al. The epilepsy-linked Lgi1 protein assembles into presynaptic Kv1 channels and inhibits inactivation by Kvbeta1. Neuron. 2006;49(5):697-706.

46. Ogawa Y, Oses-Prieto J, Kim MY, et al. Adam22, a Kv1 channelinteracting protein, recruits membrane-associated guanylate kinases to juxtaparanodes of myelinated axons. J Neurosci. 2010;30(3):1038-48.

47. Lai M, Huijbers MG, Lancaster E, et al. Investigation of Lgil as the antigen in limbic encephalitis previously attributed to potassium channels: a case series. Lancet Neurol. 2010;9(8):776-85.

48. Irani SR, Alexander S, Waters $\mathrm{P}$, et al. Antibodies to Kv1 potassium channel-complex proteins leucine-rich, glioma inactivated 1 protein and contactin-associated protein-2 in limbic encephalitis, Morvan's syndrome and acquired neuromyotonia. Brain. 2010; 133(9):2734-48

49. Kroll-Seger J, Bien CG, Huppertz HJ. Non-paraneoplastic limbic encephalitis associated with antibodies to potassium channels leading to bilateral hippocampal sclerosis in a pre-pubertal girl. Epileptic Disord. 2009;11(1):54-9.

50. Haberlandt E, Bast T, Ebner A, et al. Limbic encephalitis in children and adolescents. Arch Dis Child. 2011; 96(2):186-91.

51. Dalmau J, Lancaster E, Martinez-Hernandez E, Rosenfeld MR, Balice-Gordon R. Clinical experience and laboratory investigations in patients with anti-NMDAR encephalitis. Lancet Neurol. 2011; 10(1):63-74.

52. Dalmau J, Gleichman AJ, Hughes EG, et al. Anti-NMDA-receptor encephalitis: Case series and analysis of the effects of antibodies. Lancet Neurol. 2008;7(12):1091-8.

53. Dale RC, Irani SR, Brilot F, et al. N-methyl-d-aspartate receptor antibodies in pediatric dyskinetic encephalitis lethargica. Ann Neurol. 2009;66(5):704-9.

54. Florance NR, Davis RL, Lam C, et al. Anti-n-methyl-d-aspartate receptor (NMDAR) encephalitis in children and adolescents. Ann Neurol. 2009;66(1):11-8.

55. Irani SR, Bera K, Waters P, et al. N-methyl-d-aspartate antibody encephalitis: temporal progression of clinical and paraclinical observations in a predominantly non-paraneoplastic disorder of both sexes. Brain. 2010;133(Pt 6): 1655-67.

56. Niehusmann P, Dalmau J, Rudlowski C, et al. Diagnostic value of n-methyl-d-aspartate receptor antibodies in women with newonset epilepsy. Arch Neurol. 2009;66(4):458-64.

57. Dalmau J, Tuzun E, Wu HY, et al. Paraneoplastic anti-n-methyl-daspartate receptor encephalitis associated with ovarian teratoma. Ann Neurol. 2007;61(1):25-36.

58. Lennon VA, Wingerchuk DM, Kryzer TJ, et al. A serum autoantibody marker of neuromyelitis optica: distinction from multiple sclerosis. Lancet. 2004;364(9451):2106-12.

59. McKeon A, Lennon VA, Lotze T, et al. CNS aquaporin-4 autoimmunity in children. Neurology. 2008;71(2):93-100

60. Lotze TE, Northrop JL, Hutton GJ, Ross B, Schiffman JS, Hunter JV. Spectrum of pediatric neuromyelitis optica. Pediatrics. 2008; 122(5):e1039-47.

61. Lai M, Hughes EG, Peng X, et al. AMPA receptor antibodies in limbic encephalitis alter synaptic receptor location. Ann Neurol. 2009;65(4):424-34.

62. Lancaster E, Lai M, Peng X, et al. Antibodies to the GABA(B) receptor in limbic encephalitis with seizures: case series and characterisation of the antigen. Lancet Neurol. 2010; 9(1):67-76.

63. Graus F, Keime-Guibert F, Rene R, et al. Anti-Hu-associated paraneoplastic encephalomyelitis: analysis of 200 patients. Brain. 2001;124(Pt 6):1138-48.
64. Antunes NL, Khakoo Y, Matthay KK, et al. Antineuronal antibodies in patients with neuroblastoma and paraneoplastic opsoclonusmyoclonus. J Pediatr Hematol Oncol. 2000;22(4):315-20.

65. Saiz A, Bruna J, Stourac P, et al. Anti-Hu-associated brainstem encephalitis. J Neurol Neurosurg Psychiatry. 2009;80(4):404-7.

66. Voltz R, Gultekin SH, Rosenfeld MR, et al. A serologic marker of paraneoplastic limbic and brain-stem encephalitis in patients with testicular cancer. N Engl J Med. 1999;340(23):1788-95.

67. Dalmau J, Gultekin SH, Voltz R, et al. Ma1, a novel neuron- and testis-specific protein, is recognized by the serum of patients with paraneoplastic neurological disorders. Brain. 1999;122(Pt 1):27-39.

68. Pittock SJ, Yoshikawa H, Ahlskog JE, et al. Glutamic acid decarboxylase autoimmunity with brainstem, extrapyramidal, and spinal cord dysfunction. Mayo Clin Proc. 2006;81(9): 1207-14.

69. Liimatainen S, Peltola M, Sabater L, et al. Clinical significance of glutamic acid decarboxylase antibodies in patients with epilepsy. Epilepsia. 2010;51(5):760-7.

70. Moersch FP, Woltman HW. Progressive fluctuating muscular rigidity and spasm ("stiff-man" syndrome); report of a case and some observations in 13 other cases. Proc Staff Meet Mayo Clin. 1956;31(15):421-7.

71. Saiz A, Blanco Y, Sabater L, et al. Spectrum of neurological syndromes associated with glutamic acid decarboxylase antibodies: diagnostic clues for this association. Brain. 2008;131 (Pt 10):2553-63

72. Bingley PJ, Bonifacio E, Williams AJ, Genovese S, Bottazzo GF, Gale EA. Prediction of IDDM in the general population: strategies based on combinations of autoantibody markers. Diabetes. 1997;46(11):1701-10.

73. Bingley PJ. Clinical applications of diabetes antibody testing. J Clin Endocrinol Metab. 95(1):25-33.

74. Verrotti A, Greco R, Altobelli E, Latini G, Morgese G, Chiarelli F. Anticardiolipin, glutamic acid decarboxylase, and antinuclear antibodies in epileptic patients. Clin Exp Med. 2003;3(1):32-6.

75. Peltola J, Kulmala P, Isojarvi J, et al. Autoantibodies to glutamic acid decarboxylase in patients with therapy-resistant epilepsy. Neurology. 2000;55(1):46-50.

76. McKnight K, Jiang Y, Hart Y, et al. Serum antibodies in epilepsy and seizure-associated disorders. Neurology. 2005;65(11):1730-6.

77. Errichiello L, Perruolo G, Pascarella A, et al. Autoantibodies to glutamic acid decarboxylase (GAD) in focal and generalized epilepsy: a study on 233 patients. J Neuroimmunol. 2009;211(12):120-3.

78. Mata S, Muscas GC, Naldi I, et al. Non-paraneoplastic limbic encephalitis associated with anti-glutamic acid decarboxylase antibodies. J Neuroimmunol. 2008;199(1-2):155-9.

79. Malter MP, Helmstaedter C, Urbach H, Vincent A, Bien CG. Antibodies to glutamic acid decarboxylase define a form of limbic encephalitis. Ann Neurol. 2010;67(4):470-8.

80. Rasmussen T, Olszewski J, Lloydsmith D. Focal seizures due to chronic localized encephalitis. Neurology. 1958;8(6):435-45.

81. Rogers SW, Andrews PI, Gahring LC, et al. Autoantibodies to glutamate receptor GluR3 in Rasmussen's encephalitis. Science. 1994;265(5172):648-51.

82. Watson R, Jiang Y, Bermudez I, et al. Absence of antibodies to glutamate receptor type 3 (GluR3) in Rasmussen encephalitis. Neurology. 2004;63(1):43-50.

83. Schwab N, Bien CG, Waschbisch A, et al. CD8+ T cell clones dominate brain infiltrates in Rasmussen encephalitis and persist in the periphery. Brain. 2009;132(Pt 5):1236-46.

84. Granata T, Fusco L, Gobbi G, et al. Experience with immunomodulatory treatments in Rasmussen's encephalitis. Neurology. 2003;61(12):1807-10.

85. Quek AML, Britton J, McKeon A, et al. Autoimmune epilepsy: retrospective analysis of 26 patients. Neurology 2011; 76:A356.

86. McKeon A, Lennon VA, Pittock SJ. Immunotherapy-responsive dementias and encephalopathies. Continuum Lifelong Learning Neurol. 2010;16(2):80-101

87. Pittock SJ, Kryzer TJ, Lennon VA. Paraneoplastic antibodies coexist and predict cancer, not neurological syndrome. Ann Neurol. 2004;56(5):715-9. 
88. Davidoff AM. Pediatric oncology. Semin Pediatr Surg. 2010;19(3): 225-33

89. Murphy JJ, Tawfeeq M, Chang B, Nadel H. Early experience with $\mathrm{PET} / \mathrm{CT}$ scan in the evaluation of pediatric abdominal neoplasms. J Pediatr Surg. 2008;43(12):2186-92.

90. McKeon A, Apiwattanakul M, Lachance DH, et al. Positron emission tomography-computed tomography in paraneoplastic neurologic disorders: systematic analysis and review. Arch Neurol. 2010; 67(3):322-9.

91. Kuntz NL, Chabas D, Weinstock-Guttman B, et al. Treatment of multiple sclerosis in children and adolescents. Expert Opin Pharmacother. 2010; 11(4):505-20.

92. Recommendations for the prevention and treatment of glucocorticoid-induced osteoporosis: 2001 update. American College of Rheumatology Ad Hoc Committee on glucocorticoidinduced osteoporosis. Arthritis Rheum. 2001;44(7): 1496-503.

93. Wagner CL, Greer FR. Prevention of rickets and vitamin D deficiency in infants, children, and adolescents. Pediatrics. 2008; 122(5): $1142-52$.
94. Schimmer BP, Parker KL. Adrenocorticotropic hormone; adrenocortical steroid and their synthetic analogs; inhibitors of the synthesis and action of adrenocortical hormones. In: Hardman JG, Limbird LE, editors. Goodman and Gilman's the pharmacological basis of therapeutics 10th Ed. New York: McGraw-Hill; 2001. p. 1657.

95. Wong-Kisiel LC, Ji T, Renaud DL, et al. Response to immunotherapy in a 20-month-old boy with anti-NMDA receptor encephalitis. Neurology. 2010;74(19):1550-1.

96. Rosenfeld MR, Eichen JG, Wade DF, Posner JB, Dalmau J. Molecular and clinical diversity in paraneoplastic immunity to Ma proteins. Ann Neurol. 2001;50(3):339-48

97. Vernino S, O'Neill BP, Marks RS, O'Fallon JR, Kimmel DW. Immunomodulatory treatment trial for paraneoplastic neurological disorders. Neuro Oncol. 2004;6(1):55-62.

98. Flanagan EP, McKeon A, Lennon VA, et al. Autoimmune dementia: Clinical course and predictors of immunotherapy response. Mayo Clin Proc. 2010; 85(10):881-97. 